\title{
Product platforms as a lever of competitive advantage on a company-wide level: a resource management perspective
}

\author{
Peter E. Harland ${ }^{1} \cdot$ Zakir Uddin $^{1} \cdot$ Sven Laudien $^{2}$
}

Received: 1 December 2016 / Accepted: 30 April 2018 / Published online: 13 July 2018 (C) The Author(s) 2018

\begin{abstract}
In many industries, companies use product platforms as a means to reduce costs and obtain access to multiple market segments by developing different product variants. Product platforms are a collection of modules or parts that are common to a number of products. This commonality is developed intentionally to achieve desired effects in order to create value. The existing product platform literature provides many insights from a product-level perspective. Here, we analyze the strategic role of product platforms on a company-wide level. We discuss product platforms in the context of resource management approaches and analyze whether and to what extent understanding product platform as resources can help companies improve their strategic market position. The results are integrated into an adapted framework for product platforms as manageable resources. We emphasize the role of product platforms in the resource portfolio transition of a company: companies can use resources like skilled employees to create product platforms as superior resources. To ensure the productive use of these resources during product development, a systematic management process is required. Within that process, product platform resources have to be bundled with other resources and/or capabilities. Sustainable success for a company is achieved when its platform knowledge is synchronized with other units across management levels over time. Thinking of product
\end{abstract}

Peter E. Harland

peter.harland@tu-dresden.de

Zakir Uddin

zakir.uddin@tu-dresden.de

Sven Laudien

laudien@uni-bayreuth.de

1 Innovation Management and Entrepreneurship, Technische Universität Dresden, IHI Zittau, Markt 23, 02763 Zittau, Germany

2 Strategic Management and Organization, Universitaet Bayreuth, 95440 Bayreuth, Germany 
platforms as resources helps companies to better understand the strategic value of these platforms and find ways to make use of them to create competitive advantages.

Keywords Product platform - Resource - Capability · Resource management · Resource orchestration $\cdot$ Resource portfolio transition

JEL Classification $\quad \mathrm{D} 24 \cdot \mathrm{L} 23 \cdot \mathrm{M} 10 \cdot \mathrm{O} 31 \cdot \mathrm{O} 32$

\section{Introduction}

The concept of using product platforms is wellknown across industries: Volkswagen's automotive platform (Karlsson and Sköld 2007), Sony's Walkman platform (Sanderson and Uzumeri 1995), Black \& Decker's power tool platform (Meyer and Utterback 1993), Hewlett Packard's Deskjet printer platform (Meyer and Lehnerd 1997), and Intel's microprocessor platform (Cusumano and Gawer 2002) are some examples of successfully introduced product platforms. A product platform can increase the speed of product development, reduce development costs, and contribute to increasing product variety, therewith a product platform plays the role of a lever to raise the competitive advantage (Muffatto and Panizzolo 1996; Muffatto and Roveda 2000). The literature provides a broad variety of definitions of the term product platform. Meyer and Lehnerd (1997) define the term in a rather narrow way as a set of subsystems and interfaces that form a common structure from which a stream of derivative products can be efficiently developed and produced. McGrath (1995) defines a product platform as a collection of common elements, particularly the underlying core technology, that is implemented across a range of products. Robertson and Ulrich (1998) proposed a broader definition: they describe product platforms as a collection of assets (e.g., components, processes, knowledge, people and relationships) that are shared by a set of products. Because we focus here on product platforms as part of a whole product we do not consider them as a stage on which to present, interchange, or position something differently [e.g. as with web platforms (Zhu and Iansiti 2012) or multi-sided-platforms (Gawer 2014)]. In this paper, we adopt the product platform definition proposed byHarland and Uddin (2014) and understand a platform as a "collection of modules or parts that are common to a number of products, and this commonality is developed intentionally to attain certain effects" to create customer value. Therefore, the product platform approach is, on the one hand, a concept that enables economy of scale not by standardization on a product level but by standardization on a module level. On the other hand, this standardization on a module level economically enables, in certain market situations, more variety on the product level.

Until now, the product platform literature has contributed almost exclusively to the understanding of product platforms from the product-level perspective [e.g., discovering commonality among existing products, developing platforms, using common production lines, developing optimization techniques for platforms, and using modules (Ben-Arieh et al. 2009; Fellini et al. 2006)]. In most cases, platforms are 
considered to be merely used in products to address market-specific needs such as cost reduction or the rapid creation of variety. However, without company-wide strategic consideration and coordination it is not assured that investments in a number of product platforms will lead to sustainable competitive advantages on a companywide level. Halman et al. (2003) referred to this as a lack of a clear understanding about the potential of product platform in practice. The company-wide platform thinking can be easily traced in the stories of successful product platforms. For example, Black \& Decker changed their company strategies for production, marketing, R\&D and HRM to incorporate the power tool platform (Meyer and Utterback 1993), and Volkswagen integrated the same automotive platform under different automotive brands to satisfy different market segments (Karlsson and Sköld 2007). The results were a huge success of these platforms in the market. Beside these cases, the managerial focus of product platforms has been discussed by a number of scholars addressing issues such as platform planning, market segmentations, competencies, and platform effects (Chai et al. 2012; Meyer and Lehnerd 1997; Robertson and Ulrich 1998). However, a managerial framework that gives an overview of platform management from development to value creation of product platforms for customers as well as the link to competitive advantages on a company-wide level is still lacking. The present study fills this gap with the help of a framework based on the resource management perspective.

A company's strategic position is linked to its specific resources (Barney 1991; Rumelt et al. 1991; Wernerfelt 1984). It is therefore not surprising that in the literature this positioning becomes stronger if a company can develop capabilities to configure and deploy its available resources efficiently in different market situations (Teece et al. 1997). In order to provide a process overview of such resource configuration and deployment, Sirmon et al. (2007) proposed a resource management framework that included structuring, bundling, and leveraging resources to create value for the customer. However, this resource management task not only requires synchronization with other functional units (breadth) and management levels (depth) but also requires time alignment because the value of a resource changes over time (Sirmon et al. 2011). Sirmon et al. (2011) emphasize the challenge for resource management of being able to anticipate environmental changes. From the perspective of an organization's life cycle, these authors claim that there is a "need for research to understand how managers orchestrate the transition from one (resource) portfolio to a different yet more useful portfolio" (Sirmon et al. 2011, p. 1408).

Here, we combine the product platform concept with ideas found in the resource management literature. We focus on the following research question: Within a resource management perspective how do product platforms help companies achieve sustainable competitive advantages on a company-wide level?

We use a resource management approach to gain deeper insights into the nature of product platforms as well as a better theoretical understanding of the leverage of product platforms for competitive advantage on a company-wide level. The paper is organized as follows: In Sect. 2 we provide an overview of the product platform literature and identify a literature gap in terms of a systematic approach to using a product platform as a strategic resource on the company-wide level to achieve competitive advantage. In Sect. 3 we analyze how resource definition fits with the platform 
concept and provide additional evidence from a literature content analysis about the use of the term "resource" in the product platform literature. In Sect. 4 we adapt the resource management framework of Sirmon et al. (2007) to consider recent research on asset orchestration and portfolio transition (Sirmon et al. 2011) and integrate product platforms as superior resources. Next, we discuss the potential of product platforms as a lever of competitive advantage in strategic management. Lastly, we describe the contribution, managerial implications, and limitation of this study.

Our investigation combines insights from product platform and resource management literature by presenting a strategic approach for a resource portfolio transition: The development of key product platforms can be reasonably considered to be a part of corporate strategy with the objective of improving competitive advantage.

\section{Product platform and competitive advantage: a literature review}

Studies of the management aspects of product platforms have been in the spotlight since the 1990s. However, the commonality strategy has persisted in the engineering design literature for a long time. We review the platform literature in three perspectives: (1) a focus on engineering and design oriented literature, (2) giving an overview about the managerial literature and (3) building the bridge between the platform literature and the resource management literature by describing the strategic value of platforms as resources.

Design of platform and platform-based product development The following Fig. 1 illustrates the basic understanding of product development based on a product platform (product platforms are common modules used by several products).

In the literature, several methods have been described to support product platform development, starting with the examination of a platform concept. For example,Simpson et al. (2001) have proposed the product platform concept exploration method (PPCEM)

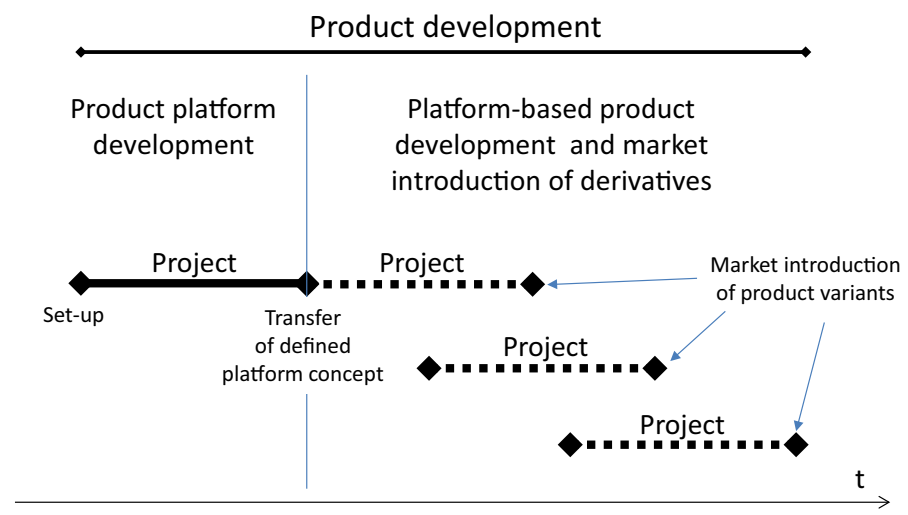

Fig. 1 Development of product platforms and platform-based products [author's illustration based on Harland and Yörür (2015)] 
to evaluate a product platform before starting platform development. The core idea behind platform development is to ensure commonality among platform-based products. Otto and Hölttä-Otto (2007) proposed a platform assessment tool for preliminary concept scanning. Fellini used a sensitivity-based analysis and a quantitative platform component selection technique to determine the best platform solution (Fellini et al. 2004, 2005). Other researchers have focused on different aspects of platform development including product platform design optimization (Jariri and Zegordi 2008; Khajavirad et al. 2009; Wei et al. 2009), building of commonality indices (Martin and Ishii 2002; Thevenot and Simpson 2006, 2007) and the introduction of a multi-objective genetic algorithm for commonality (Simpson and D’Souza 2004). Suh et al. (2007) described a flexible product platform design approach that is different from previous optimization approaches in that the platform developed can be stretched to include other derivatives.

Platform-based product development is targeted to maximize the use of the platform as much as possible. Several authors have focused on platform-based product development and assessment tools for product family optimization (de Weck et al. 2003), a knowledge-based system for derivative products (Zha and Sriram 2006), the design of a derivative using a variation-based model (Nayak et al. 2002), homogeneity or heterogeneity metrics of derivatives to estimate platform leveraging (Alizon et al. 2010), and an automatic design method to develop product variants (AlGeddawy and ElMaraghy 2013). Some authors have also proposed some indices that helps guide the generation of platform-based products [e.g., the Generational Variety Index and the Coupling Index (Martin and Ishii 2002), the Penalty Vector (Fellini et al. 2004) and the Design Customizability Index and the Process Customizability Index (Jiao and Tseng 2004)]. The design issues are mainly discussed in these papers where commonality plays a vital role. In most cases, customer integration and diversification are not addressed.

The engineering-oriented literature includes several methods to handle engineering issues on the platform side and/or in the usage of the platforms for product variants. Therefore, this literature stream is mainly focused on operational problems on the product level.

Managerial frameworks of product platform The need for platform management came under the spotlight as soon as Wheelwright and Clark (1992) defined platform as a foundation for a product family. The platform project requires special managerial attention because it can be incremental, modular, architectural, or radical in nature depending on resource requirements, organization principles, and management styles (Sköld and Karlsson 2013). According to Robertson and Ulrich (1998), the planning phase of product platform is crucial. Meyer and Lehnerd (1997) proposed an integrative model for product platform development. In this model, consumer insights, product technology, the manufacturing process, and organizational capabilities are considered to be common building blocks of product platform development. The development of the platform entails the generation of updates and upgrades to maintain the company's competitive advantage in markets (Meyer and Dalal 2002; Meyer and Lehnerd 1997; Meyer and Utterback 1993). Chai et al. (2012) developed a model in which process, knowledge, and organizational factors influenced platform competencies-namely reusability, compatibility, and 
extensibility. According to these authors, platform competency is a precondition for platform performance. Product platform competency itself is positively influenced by factors such as a formalized development process, knowledge sharing across platform-based products, continuity of platform-based product development teams, and the existence of a champion in platform-based product development. Among different external factors, demand-side characteristics and the speed of environmental change are two contingencies that influence the economic success of a product platform (Magnusson and Pasche 2014). Several managerial indices have been proposed to evaluate the effectiveness of a product platform including platform efficiency and platform effectiveness (Meyer and Lehnerd 1997; Meyer et al. 1997) and market efficiency (Zha and Sriram 2006). Sawhney (1998) discussed portfolio thinking with product platform. Several effects of product platforms have been highlighted by different authors (Pasche et al. 2011; Robertson and Ulrich 1998).

These models have largely considered specific requirements of platform development and do not provide a full picture of profits gained or competitive advantages gleaned on a company-wide level with the help of product platform. Pirmoradi et al. (2014) argued in the same direction. As noted previously, we adopt in this paper a resource management perspective using a resource management framework. Therefore, we examine to what extent the strategic importance of this perspective has been addressed in the platform literature.

Strategic importance of product platforms as resources From a strategic point of view, product platforms can play an important role because they aim to enact cost reductions, reductions in the time to market reduction, or an increase of product variants (Meyer and Lehnerd 1997; Robertson and Ulrich 1998; Sawhney 1998). Harland and Uddin (2014) integrated 27 positive product platform effects in a framework and demonstrated benefit dues to a product platform. In order to understand the use of the term "resource" in a product platform context, we conducted a qualitative content analysis (Hsieh and Shannon 2005; Kondracki et al. 2002) of published articles to better understand to what extent the term "resource" has been used in a product platform context. We screened out 116 product platform articles from the journal databases SCOPUS, EBSCO and PDMA (JPIM) for the period 1993-2014. We ended up with 69 platform documents with 466 instances of the term "resource.'In most cases, the instances described the input resources required for product platform development. We found only 12 articles in which the authors implicitly noted the strategic importance of product platforms as a resource (see the Appendix). Gedell and Johannesson (2013) directly defined product platform as a set of resources. Product platform helps companies use existing resources better (Agrawal et al. 2013; Karlsson and Sköld 2007; Robertson and Ulrich 1998; Shooter et al. 2005), and developing a good platform requires internal assessment of resources (Hofer and Halman 2005; Jiao et al. 2007; Ramdas 2003; Sawhney 1998). Sköld and Karlsson (2013) argued that the product platform development impacts the resource base of an organization. Making resources available for platform leads to several market advantages: increased cost and time efficiency and better technology leverage (Halman et al. 2003).

Therefore, platform management is directly related to an organization's resource management. However, the context of platforms as resources has not been examined 
yet. No study has used the resource context of product platforms to explain the competitive advantage with the product platform. Therefore, no framework based on resource context has been found that explains the platform management and how a platform contributes to a company's value-creation process.

\section{Product platforms from a resource management perspective}

Wernerfelt (1984) defined resources as "those (tangible and intangible) assets which are tied semi-permanently to the firm." From a strategic point of view, Barney (1991) defined resources as all assets, capabilities, organizational process, firm attributes, information, knowledge, etc. that help to improve a firm's strategic competency. In other words, a "firm can use it to conceive of and implement their strategies" (Barney 1991). Therefore, companies need to search for resources that can be considered to be a source of competitive advantage (Peteraf 1993; Wernerfelt 1989). Barney (1991) defined four attributesnamely valuable, rare, inimitable, and organizationally exploitable (VRIO)— to judge the potential of a resource regarding its competitive advantages. Below, we examine Barney's VRIO criteria for product platforms to assess their resource potentiality.

Resources should be valuable such that they can create value either by exploiting opportunities or by reducing risks (Barney 1991). Product platforms are valuable because they show potential for both exploiting opportunities and reducing risks. In case of the Black \& Decker motor platform, the developed product platform helped to exploit a new market of electrical motors after new safety regulations at a cheaper price (Meyer and Lehnerd 1997). A product platform helps to boost the speed of product development, reduces the costs of product development, and supports easier variation of products (Ben-Arieh et al. 2009; Halman et al. 2003; Meyer and Lehnerd 1997; Muffatto 1999). Product platforms create value because they ensure efficient use of other resources, reduce excess resource consumption, and keep enough diversification in derivatives (Gawer and Cusumano 2014; Halman et al. 2003; Hofer and Halman 2005; Jiao and Helander 2006; Robertson and Ulrich 1998; Shooter et al. 2007). Due to the use of proven modules and the reuse of established processes, product platforms reduce design risks and process uncertainties (Gonzalez-Zugasti et al. 2000; Koufteros et al. 2005).

Resources should be rare among current and potential competition (Barney 1991). Product platforms are rare because they are the result of a unique creation process and because (at least in a specific market segment) not every company possesses a platform. In addition, a company develops platforms that fit with their product line. For example, double insulation, a standard interface (plug-in), and options for variations in power with length made the Black \&Decker motor platform so unique that no other competitor even thought about such a platform (Meyer and Lehnerd 1997). Similarly, Sony Walkman platforms were rare in that they were very flexible and the company could bring about a new design of the Walkman very easily (Sanderson and Uzumeri 1995). Product platform development typically requires a number of resources such as R\&D expenditures, various development resources, testing resources, design resources, technological resources, manufacturing resources, and production resources. Therefore, it is not easy for every company to dedicate its resources to platform development. 
Resources should be imperfectly imitable (Barney 1991). Product platforms are used by companies to gain a competitive advantage. Therefore, companies try to make their platform as inimitable as possible. Although product platforms reduce product development complexity, a product platform itself is not simple to develop. As ElMaraghy et al. (2013) noted, product variety increases complexity in platform development, and many companies set their platform goal to develop a number of variants easily. When "the variety of functional requirements becomes too large, the platform may become too demanding to develop, too expensive to build and too complex to operate reliably" (Simpson et al. 2006). The Sony Walkman platform is a good example of inimitability of a product platform. Although Japanese competitors to Sony was very much keen to develop high-quality imitations of the Walkman, they took a long time to develop them (Sanderson and Uzumeri 1995). Sony was able to become a market leader because of its four-base platform that helped it develop 250 models (Sanderson and Uzumeri 1995). Barney (1991) explained that one of the core source of inimitability of a resource depends on the place and time necessary to acquire and exploit that resource. Therefore, resources are imperfectly imitable if firms do not possess time- and place-dependent resources. In case of the motor platform, Black \& Decker came up with their new platform in the United States where new regulations rendered all previous motor designs obsolete (Meyer et al. 1997). Therefore, the new motor platform used in power tools at that time was completely new to others, which made the product platform imperfectly imitable. In addition, platform evolution and renewal (Meyer and Lehnerd 1997; Meyer and Utterback 1993) made the imitation of a platform more challenging.

Lastly, a company must be in a state to "organizationally exploit" a resource. A resource can include other companies' resources and capabilities such as reporting structures, management systems, control systems, and compensation policies, which should all be aligned to exploit a resource (Barney 1997, 2011). Product platforms require organizational resources and capabilities to be successful. Chai et al. (2012) found that formalized development process, knowledge sharing across platformbased products, platform team consistency in product development, and the presence of a platform champion all had a positive impact on product platform competency. Thomas (2014) argued that an organization's strategic flexibility has a positive influence on the relation between platform design supports and market performance. Meyer and Lehnerd (1997) demonstrated the importance of building organizational capabilities for Black \& Decker's motor platform for power tools and considered such capabilities to be one of the building blocks of product platforms.

In summary, a product platform fits well within the resource criteria of VRIO suggested by Barney (1995) to create a sustainable competitive advantage. However, there is one limitation: From our point of view, the first criterion-valuabledepends on the context. There might a platform valuable for a small business unit in their context, but it is not in the context of the entire company (Fig. 2).

Therefore, from a resource management perspective we can posit that a product platform is a kind of resource that possesses the potential to confer competitive advantages to the whole company. Halman et al. (2003) clearly depicted an existing gap in terms of a clear understanding about the potential of product platform in practice. Up until now, no specific framework has been defined for product platforms, as noted in the previous 
review section. Therefore, a management framework for product platform resource is presented in the next section based on work by Sirmon et al. (2007).

\section{A strategic resource management framework for leveraging competitive advantage by product platforms}

A platform is not only a specific type of resource that results from an intentional resource transition. It can also be viewed as a source of a dynamic capability because product platforms provide more flexibility in terms of product attributes, which in turn allows for a better reaction to changing markets as well as customer requirements in terms of costs and variance (Gao et al. 2009; Suh et al. 2007). Hence, a platform links the resource-based view and the dynamic capability approach to a certain extent because the ability to develop new products or to adjust to existing products is often addressed in the literature as a dynamic capability (Maniak et al. 2014).

The dynamic resource management framework of Sirmon et al. (2007) describes the construction of a resource portfolio and the building of capabilities based on resources to exploit market opportunity. Capabilities are companies' "capacity to deploy resources" to attain certain goals (Amit and Schoemaker 1993), and dynamic capabilities are "the firm's ability to integrate, build, and reconfigure internal and external competences to address rapidly changing environments" (Teece et al. 1997, p. 516).

In the following section, we adapt Sirmon et al.'s resource management model based on findings of the previous chapters by bringing in activities related to developing and exploiting product platforms (see Fig. 3). Sirmon et al. (2007) defined resource portfolio as "the sum of all firm controlled resources (i.e., tangible and intangible assets)."

Perspective on a company-wide level (strategic resource management)
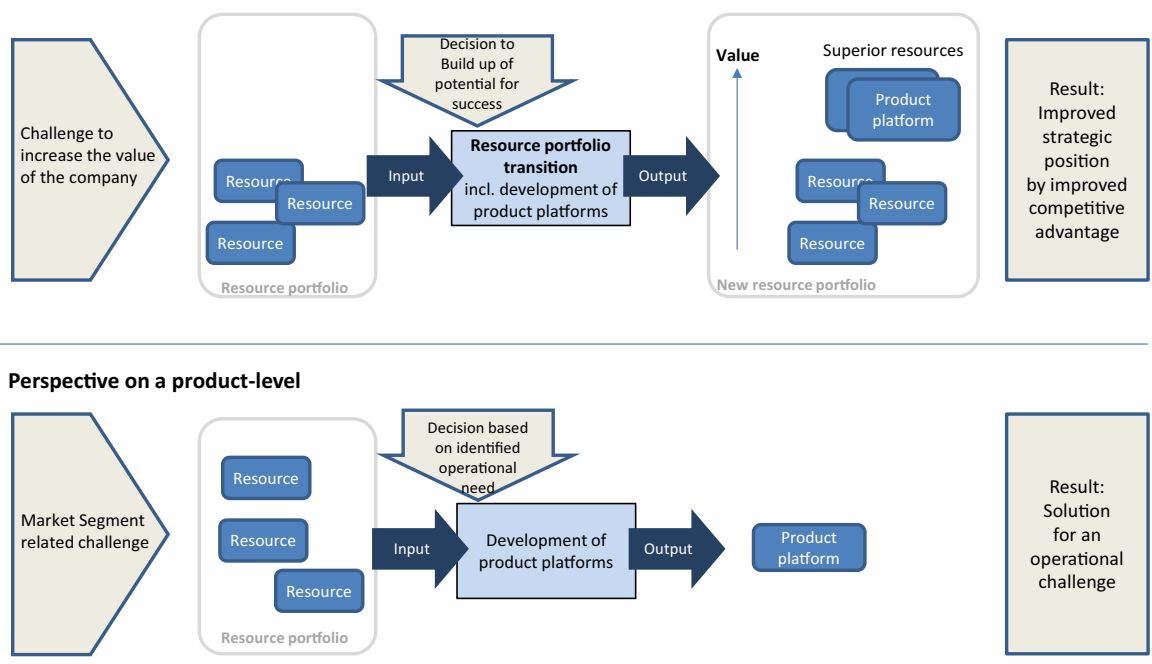

Fig. 2 Product-level-perspective of the platform approach versus resource management in companylevel perspective 


\section{Integration of product platform resources in the resource management framework}

Resource portfolio structuring and resource portfolio transition The first step of the resource management process starts with the structuring of the resource portfolio, which is "the process by which firms acquire, accumulate, and divest resources" (Sirmon et al. 2007). Sirmon et al. (2007) define acquiring as purchasing of resources, accumulating as the internal development of resources, and divesting as getting rid of resources that do not add value to competitive advantage. Like other resources, product platforms can also be accumulated, acquired, or divested (Sirmon et al. 2007).

When a company develops a resource internally, resource accumulation helps the company improve their isolating mechanisms (e.g., causal ambiguity) (Sirmon et al. 2007). This process is the most commonly used technique for structuring a product platform resource. Companies accumulate product platform resources by developing product platforms [e.g., the development of the Sony Walkman and Black \& Decker power tool platforms (Meyer and Lehnerd 1997; Sanderson and Uzumeri 1995)]. The accumulation of product platform is showed in Fig. 3 where product platforms are developed internally. It takes other resources like components to create product platforms. According to Peteraf (1993), a superior resource is different from other resources in that it can be produced economically and/or it can better satisfy customer needs. Therefore, platform development is - at least to a certain extent - a kind of resource portfolio transition, and platforms are the result of the transition from resources of lower value to superior resources.

Acquiring is the process of purchasing resources (e.g., equipment, intellectual capital, etc.) from strategic factor markets (Sirmon et al. 2007). It is also possible to acquire product platform resources from other companies. An example of acquiring a platform resource is Microsoft's purchase of the QDOS operating system (the precursor to MS-DOS) from Seattle Computer in 1980 (Makadok 2001).

According to Sirmon et al. (2007), companies are also in a position to divest resources when no further updates of the resource are possible or when they no longer represent value for their resource portfolio. The same situation persists for product platforms, and many examples of such obsolete platforms are available in the literature. The life span of a platform is becoming shorter as markets become more global, diverse, and competitive (Sanderson and Uzumeri 1995). However, as suggested by Meyer and Lehnerd (1997), managers can always consider options like platform evolution and platform renewal to shape the value of the product platform, thereby extending its life.

Bundling product platform with other resources According to Sirmon et al. (2007), resource bundling is a process of integrating resources from the resource portfolio to create capabilities, which allows companies to take specific actions. In order to attain specific targets, product platforms are bundled to create capabilities. Product platforms are bundled with other resources so that capabilities are developed to use the platform properly to gain competitive advantages.

Sirmon et al. (2007) defined three types of bundling process: stabilizing, enriching, and pioneering. Stabilizing aims to make minor incremental improvements in existing capabilities (Sirmon et al. 2007). In case of product platforms, integrating formal training and practical experience with product platforms are examples of stabilizing platform resources that ensure better use of platform knowledge. Formal 


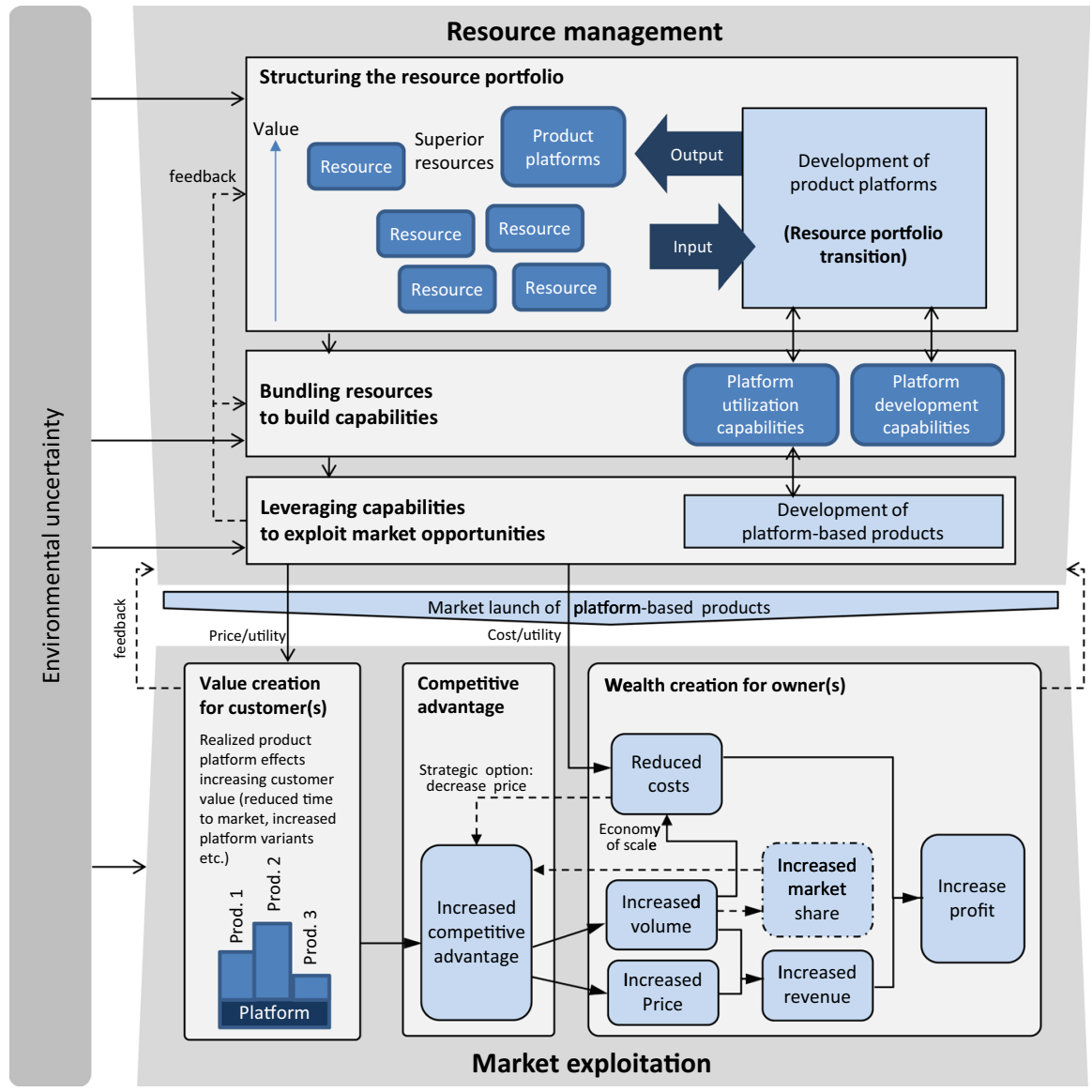

Fig. 3 Framework for product platforms as manageable resources [author's illustration based on Sirmon et al. (2007, p. 276) as well as Harland and Uddin (2014, p. 272)]

training and practical experience in product platform design definitely differentiate a novice from an expert (Fung and Chong 2007).

The enriching bundling process targets extending and elaborating on a current capability (Sirmon et al. 2007). The modular design of products, early market prediction, and standard interfaces of other components are example of capabilities and resources that are bundled with product platforms to extend and simplify the platform's usability in different products. Pioneering refers to the integration of completely new resources with the resources in a resource portfolio to create new types of capability (Sirmon et al. 2007). For product platforms, adding new optimization techniques and strategy helps to develop capabilities to exploit the maximum potential of a product platform resource. For example, we refer to the reader to the different optimization techniques presented by Li et al. (2007) and Luo et al. (2010).

The bundling of product platforms with other resources will result in capabilities that ensure efficient use of the platform in different product variants. We refer 
these capabilities as platform utilization capabilities. These capabilities are very much needed because the deployment of successful platform resources depends on understanding customers' needs, product technologies, manufacturing processes, and organizational capabilities (Meyer and Lehnerd 1997).

We also suggest that another group of capabilities referred to as platform development capabilities are as much needed as platform utilization capabilities. As noted earlier, the development of a platform resource is itself a resource transition. Therefore, before starting platform development companies need to build platform development capabilities - such as a modular design capability, an ability to design reusable components, technical capabilities or market prediction capabilities-using existing resources. The primary interest motivating the development of a product platform is to use it in different product variants.

Leveraging (platform) capabilities Peteraf (1993) argued that productivity of superior resources relies on their employment and the skill of implementation. The leveraging step is about the application of capabilities to create value for customers and wealth for the company and this step involves three sub-processes: mobilizing, coordinating, and deploying (Sirmon et al. 2007). Mobilization is about the capability of a configuration to exploit market opportunities, coordination is about the coordination of that capability configuration, and deployment is about the physical implementation of the chosen capability configuration (Sirmon et al. 2007).

Companies leverage their platform capabilities by designing and launching platform-based products to exploit market opportunities. Developing successful platform-based products requires mobilization, coordination, and deployment of capabilities (Sirmon et al. 2007). Product platforms help with the mobilization of capabilities because they allow different products to be customized to meet specific customer requirements (Jiao et al. 2007; Qu et al. 2011). Developing and running a product platform successfully requires coordination between marketing, $R \& D$, and manufacturing. If a company is not able to guarantee a minimum amount of internal coherence and collaboration, it will not be able to fulfill its customers' needs (Chai et al. 2012). To create value for customers, it is necessary to deploy capabilities in the right way (Sirmon et al. 2007). The success story of Black \&Decker is worth noting here. The company provided a "war room" in which people from different functional units were given the opportunity to judge the product design (Meyer and Lehnerd 1997). Product platform resources are used to create flexibility in a company's scope of action so that it can act according to its customers' needs. In this regard, managerial tacit knowledge can help to boost coordination and deployment abilities.

Every step (resource structuring, capability building, and leveraging) in this stage is linked with feedback loops so that changes can be incorporated to ensure a better resource portfolio. If disadvantages appear in a certain bundle of resources, an adaptation of the bundle is required (e.g., other resources, such as engineers, replace the use of certain modules of a platform).

Market exploitation Sirmon et al. (2007) argued that capabilities are leveraged depending on market uncertainties to exploit market opportunities. Product platforms create value for customers in terms of quality improvement, variants, ease of 
use (due to common functionality among variants), reduction in time to market, and price reduction (Halman et al. 2003; Harland and Uddin 2014; Meyer and Lehnerd 1997; Robertson and Ulrich 1998). These effects improve the competitive position of a company in the marketplace (Halman et al. 2003). A competitive advantage allows companies to increase profitability either by increasing their prices and/or by giving them the chance to sell larger volumes of goods (Harland and Uddin 2014).

Product platforms also help companies reduce their production costs due to common components, the use of the same production line for different variants, gaining economies of scale due to producing a large volume of common components, simplification of inventory management, and savings in logistic costs (Meyer and Lehnerd 1997; Robertson and Ulrich 1998; Suh et al. 2007). All in all, the wealth creation of a company might be positive via increased revenue due to competitive advantages and/or reduced costs. Therefore platform resources are-like noted above-superior (Peteraf 1993) because they help to develop products that are more economical and/or better suited to satisfying customers' needs.

Consistent with the findings of Meyer and De Tore (2001), we also suggest that companies need to have a good understanding of customers' latent and perceived needs in order to create value for them. Feedback from the market exploitation stage helps to finetune the resource base and capability deployment to attain greater market exploitation.

Environmental uncertainly and platform resource management From resource structuring to market exploitation, companies need to be aware of the market situation. Due to the long life span of product platforms, this analysis has to done carefully (Meyer and Utterback 1993). Black \&Decker aligned their production strategy by predicting environmental changes: emerging competitors, inflation and rising costs of labor, materials, services and capital goods, and new insulation regulations (Meyer and Lehnerd 1997). The platform resource makes it easy to bring about small changes in products, which results in suitable variants to address market uncertainties. Considering platform flexibility can add value in that case to face unexpected market situations in a better way (Suh et al. 2007).

\section{Discussion}

In the previous chapters, we argued that product platforms can be viewed as resources. In the resource management framework adapted from Sirmon et al. (2007), we illustrated the role of the (superior) resource product platform in the resource management of companies and in creating value for customers. Based on the previous discussion, the role of product platforms in increasing competitive advantages are discussed below.

Building-up platform resources introduces effects leading to a better competitive position in the market Our results reveal that product platforms are resources that potentially create a number of competitive advantages. For example, a cost reduction potential is achieved by a platform resource that enables sharing a high commonality 
of materials, components, and even manufacturing assemblies (Krishnan and Gupta 2001; Lundbäck and Karlsson 2005; Muffatto 1999; Park et al. 2008; Robertson and Ulrich 1998). Flexibility is introduced into companies via product platforms when companies become capable of reacting to changing markets and customer requirements. Product platforms help companies to also easily increase product variety and incorporate flexibility into their production and development processes (Ben-Arieh et al. 2009; Gonzalez-Zugasti et al. 2000; Halman et al. 2003; Muffatto and Roveda 2000). These arguments reveal why product platforms foster competitive advantages over the long run.

Product platform resources require a company to go through a systematic management process However, it is not likely that developing a product platform will automatically ensure market success and sustainable competitive advantage. As noted by Halman et al. (2003), there appears to be a lack of awareness among practitioners of the strategic relevance of product platforms. A systematic management process for product platform development and utilization will be useful to increase the degree of management attention paid to platform-related issues and their impact on competitive advantage. Product platforms might therefore represent a part of corporate strategy. In this context, our resource management framework helps management to understand how to handle product platform resources from development to exploitation. Given the fact that environmental impacts change often, a company must adapt its resource portfolio regularly.

Building platform-related capabilities are an important component of organizations' ability to realize platform-based product success As noted above, adopting a platform strategy will not automatically result in the achievement of certain positive goals such as cost reductions or reduction in time to market. In addition, certain negative or unachievable effects such as innovation barriers, high investment risks, or the risk of a product being too complex have been highlighted by several authors (Alizon et al. 2010; Halman et al. 2003; Meyer and Lehnerd 1997; Robertson and Ulrich 1998). Obviously, the existence of a platform does not guarantee success. At worst, product platforms might even appear to be more of a "core rigidity" (Leonard-Barton 1992). The platform resource has to be bundled with other resources and/or capabilities to achieve a competitive advantage. For example, companies that have an interface-simplifying capability or a modular design capability will use their platforms more efficiently than competitors without these capabilities. Similarly, companies that include platform experts or that possess strong market prediction capabilities can utilize their platform knowledge better than companies that lack these traits. In this paper, for simplification we considered two basic platform capabilities - namely platform development capabilities and platform utilization capabilities - into our framework. In our viewpoint, this potential field of research merits more attention to exploit the full advantage of product platforms.

Synchronization of platform thinking in the organization is essential to sustain platform-based product success Consistent with the idea of resource orchestration developed by Sirmon et al. (2011), platform resources need to be synchronized 
across different functional units (breadth), management levels (depth), and product life cycles (time).

Orchestration across functional units (breadth) starts with the development of product platforms, which enables different functional units of companies to integrate the predicted future needs of their customers. Empirical studies have supported the idea that cross-functional integration improves efficiency in terms of new product development (Brettel et al. 2011; Griffin 1997; Koufteros et al. 2005) as well as the view that platform development projects are an integral part of product development (Tatikonda 1999). Knowledge about a product platform needs to be shared with other units to help them learn about the final products (e.g., a marketing manager can be better marketer if he/she understands not only the products of his/her own business unit but also those of other business units using the same platform).

Similarly, the coordination of product platforms targeting managerial hierarchies (depth) can help to set the right focus within the company and increase motivation. Koufteros et al. (2005) argued that such early-phase orchestration helps to include the voice of lower-level managers in the final decision-making stage of product development.

The last type of orchestration concerns the dimension of time. Like other resources, the value of product platform resources tends to diminish over time (Meyer and Lehnerd 1997; Sirmon et al. 2011). Therefore, product platforms have to be designed in such a way that they can be adjusted to time-related market changes over their usage period (McGrath 1995). Meyer and Lehnerd (1997) described this phenomenon as an evolution of product platforms, whereby the initial platform should be able to incorporate certain changes in time or be developed into a new platform if necessary. We believe that product platform resource orchestration helps companies to manage the transition from one resource portfolio to a better one and thereby attain a new stage in an organization's life cycle (Sirmon et al. 2011).

\section{Conclusions}

We have discussed product platforms from a value-creation perspective based on a resource management viewpoint. On the one hand, resources are used to create product platforms, which is not a new idea. On the other hand, we provide evidence for an understanding of product platforms as resources themselves, and we thereby enhance the product platform literature considerably. From a resource management perspective, product platform concepts are not only a solution for a specific market situation or a technological challenge but also a strategic instrument on a company-wide level: a resource that could be a target to invest in systematically. Our work provides (1) a descriptive model of a value-creation process for product platforms, (2) a theoretical basis for new research focusing on product platform management, and (3) initial insights into the enrichment of corporate strategy via product platform concepts. Since this view is in line with the resource definitions provided by resource management literature, we are able to link two research streams that were, up to this point, largely unrelated. The insights that we have gathered allow product platforms to be classified as resources. These product platform resources can be utilized in the joint planning of resources and could even replace other 
resources within the process of value creation. We consider platforms to be superior resources for two reasons: First, their development is the result of a resource transformation process; second, as a company gains experience, the value of the product platform resources increases via their use. Therefore, it is very likely that companies will be willing to spend finite resources to develop a product platform because they view it as an internally created source of competitive advantage.

Considering product platforms as a part of resource management has several managerial implications. Companies are almost independent in creating product platforms. Therefore, product platforms enable companies to react flexibly to market changes and to adapt to the market's changing characteristics. Nevertheless, utilizing product platforms involves higher coordination requirements, which companies need to take into account. Apart from enhancing the company's scope of action, opportunities to bundle the superior resource of the product platform with other resources allows companies to form collaborations with competitors, suppliers, and customers. One such collaboration with customers involves providing the platform itself, which enables partners to create their own products based on the platform (defined by Gawer and Cusumano (2014) as an "industry platform"). Although product platforms allow for the creation of competitive advantages in terms of costs, quality, and time, any incorrect strategic decision on product platforms related to design, target market definitions, and sharing of platform components can result in multiple severe risks. To avoid such risks, companies need to incorporate the product platform not only into the product development processes but also into the overall company strategy development.

We have extended the resource literature via a new class of resources. Furthermore, we have provided a new perspective on product platforms, which introduces a broader view of them. These advancements maybe useful for further discussions in this field and also serve to be beneficial from an interdisciplinary, theoretical perspective.

However, we acknowledge that our study is affected by some limitations. First, we selected a resource management perspective to explain the "product platform" phenomenon. Other theoretical perspectives might be worth looking at as well. Within the resource management perspective, we focused on the model of Sirmon et al. (2007); we identified no alternatives. The literature search that we carried out had limited empirical coverage. However, because our topic is a very new one that requires fundamental research, we believe that it is necessary and reasonable to approach this topic from a more conceptual perspective and providing solid theoretical background for future empirical research.

Open Access This article is distributed under the terms of the Creative Commons Attribution 4.0 International License (http://creativecommons.org/licenses/by/4.0/), which permits unrestricted use, distribution, and reproduction in any medium, provided you give appropriate credit to the original author(s) and the source, provide a link to the Creative Commons license, and indicate if changes were made.

\section{Appendix}

See Table 1. 


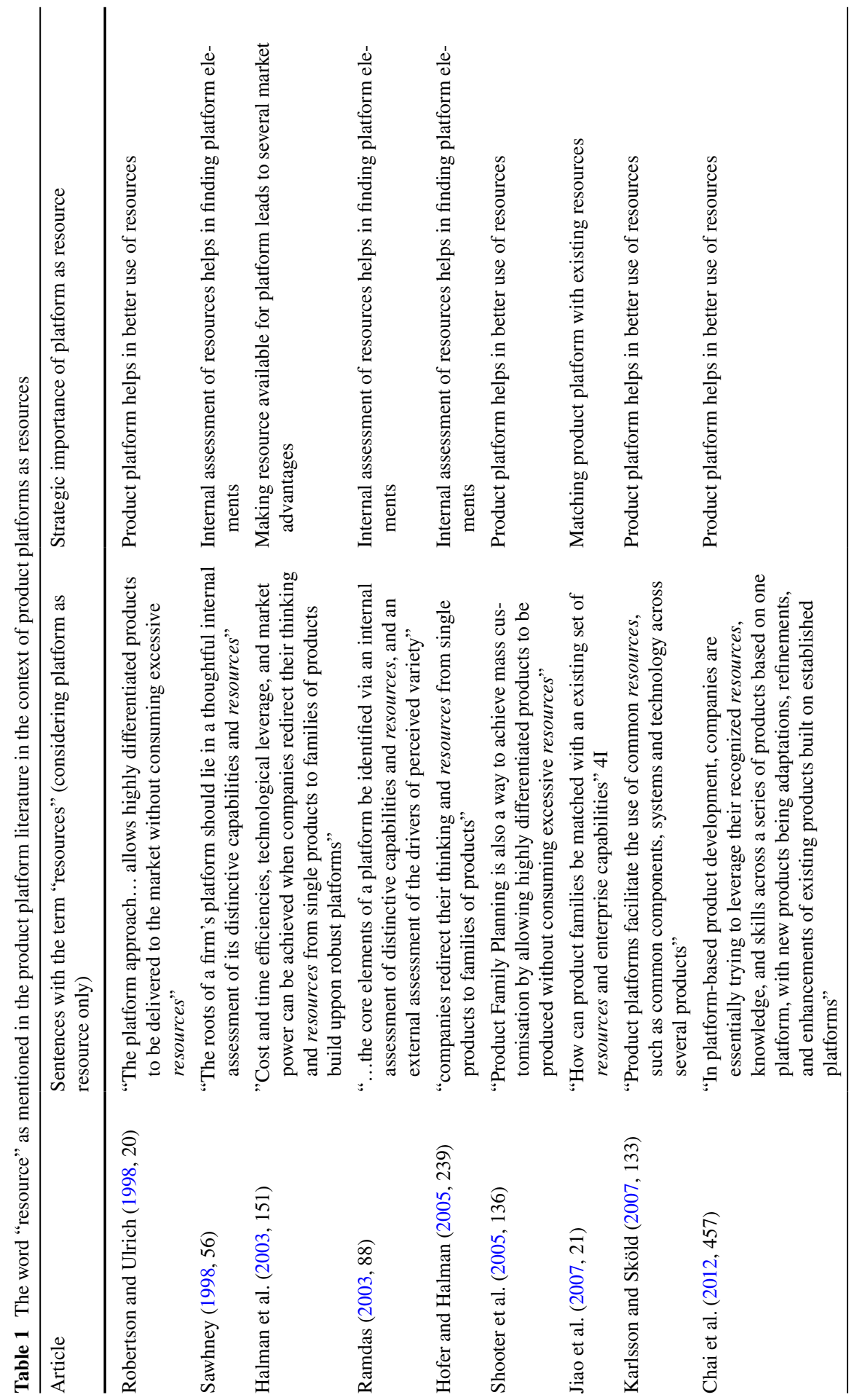




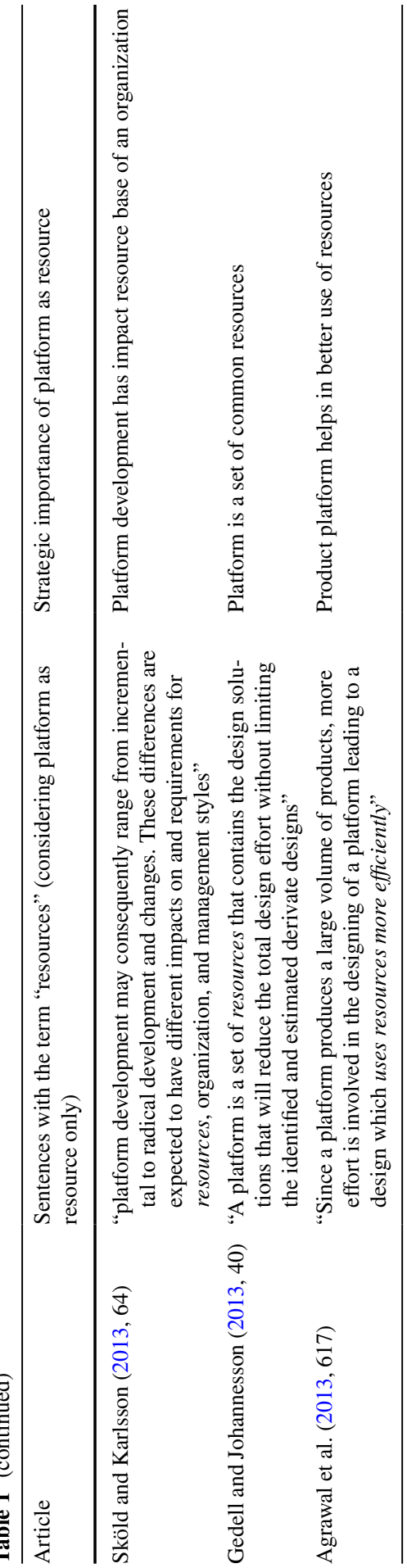




\section{References}

Agrawal T, Sao A, Fernandes KJ, Tiwari MK, Kim DY (2013) A hybrid model of component sharing and platform modularity for optimal product family design. Int J Prod Res 51:614-625. https://doi. org/10.1080/00207543.2012.663106

AlGeddawy T, ElMaraghy H (2013) Reactive design methodology for product family platforms, modularity and parts integration. CIRP J Manuf Sci Technol 6:34-43. https://doi.org/10.1016/j.cirpj .2012.08.001

Alizon F, Shooter SB, Simpson TW (2010) Recommending a platform leveraging strategy based on the homogeneous or heterogeneous nature of a product line. J Eng Des 21:93-110. https://doi. org/10.1080/09544820802236211

Amit R, Schoemaker PJH (1993) Strategic assets and organizational rent. Strateg Manag J 14:33-46

Barney JB (1991) Firm resources and sustained competitive advantage. J Manag 17:99-120

Barney JB (1995) Looking inside for competitive advantage. Acad Manag Exec 1993-2005(9):49-61. https://doi.org/10.2307/4165288

Barney J (1997) Gaining and sustaining competitive advantage. Addison-Wesley, Reading, MA

Barney J (2011) Gaining and sustaining competitive advantage. Pearson, Boston, MA

Ben-Arieh D, Easton T, Choubey AM (2009) Solving the multiple platforms configuration problem. Int J Prod Res 47:1969-1988. https://doi.org/10.1080/00207540701561520

Brettel M, Heinemann F, Engelen A, Neubauer S (2011) Cross-functional integration of R\&D, marketing, and manufacturing in radical and incremental product innovations and its effects on project effectiveness and efficiency. J Prod Innov Manag 28:251-269. https://doi.org/10.111 1/j.1540-5885.2011.00795.x

Chai K-H, Wang Q, Song M, Halman JIM, Brombacher AC (2012) Understanding competencies in platform-based product development: antecedents and outcomes. J Prod Innov Manag 29:452-472. https://doi.org/10.1111/j.1540-5885.2012.00917.x

Cusumano MA, Gawer A (2002) The elements of platform leadership. MIT Sloan Manag Rev 43:51-58

de Weck OL, Suh ES, Chang D (2003) Product family and platform portfolio optimization. In: ASME 2003 international design engineering technical conferences and computers and information in engineering conference, 2003. American Society of Mechanical Engineers, pp 175-185

ElMaraghy H, Schuh G, ElMaraghy W, Piller F, Schönsleben P, Tseng M, Bernard A (2013) Product variety management. CIRP Ann 62(2):629-652

Fellini R, Kokkolaras M, Michelena N, Papalambros P, Perez-Duarte A, Saitou K, Fenyes P (2004) A sensitivity-based commonality strategy for family products of mild variation, with application to automotive body structures. Struct Multidiscip Optim 27:89-96. https://doi.org/10.1007/s0015 8-003-0356-X

Fellini R, Kokkolaras M, Papalambros P, Perez-Duarte A (2005) Platform selection under performance bounds in optimal design of product families. J Mech Des 127:524-535. https://doi. org/10.1115/1.1899176

Fellini R, Kokkolaras M, Papalambros PY (2006) Quantitative platform selection in optimal design of product families, with application to automotive engine design. J Eng Des 17:429-446. https://doi. org/10.1080/09544820500287797

Fung RYK, Chong PY (2007) An active styling platform for designing and developing product families. J Intell Manuf 18:47-58. https://doi.org/10.1007/s10845-007-0006-Z

Gao F, Xiao G, Simpson TW (2009) Module-scale-based product platform planning. Res Eng Des 20:129-141. https://doi.org/10.1007/s00163-008-0061-2

Gawer A (2014) Bridging differing perspectives on technological platforms: toward an integrative framework. Res Policy 43:1239-1249. https://doi.org/10.1016/j.respol.2014.03.006

Gawer A, Cusumano MA (2014) Industry platforms and ecosystem innovation. J Prod Innov Manag 31:417-433. https://doi.org/10.1111/jpim.12105

Gedell S, Johannesson H (2013) Design rationale and system description aspects in product platform design: focusing reuse in the design lifecycle phase. Concurr Eng 21:39-53

Gonzalez-Zugasti JP, Otto KN, Baker JD (2000) A method for architecting product platforms. Res Eng Des 12:61-72

Griffin A (1997) PDMA research on new product development practices: updating trends and benchmarking best practices. J Prod Innov Manag 14:429-458 
Halman JIM, Hofer AP, van Vuuren W (2003) Platform-driven development of product families: linking theory with practice. J Prod Innov Manag 20:149-162. https://doi.org/10.1111/1540-5885.2002007

Harland PE, Uddin Z (2014) Effects of product platform development: fostering lean product development and production. Int J Prod Dev 19:259-285

Harland PE, Yörür H (2015) Decisions in product platform development projects. Int J Innov Technol Manag. https://doi.org/10.1142/s0219877015500017

Hofer AP, Halman JIM (2005) The potential of layout platforms for modular complex products and systems. J Eng Des 16:237-255. https://doi.org/10.1080/09544820500031518

Hsieh H-F, Shannon SE (2005) Three approaches to qualitative content analysis. Qual Health Res 15:1277-1288. https://doi.org/10.1177/1049732305276687

Jariri F, Zegordi SH (2008) Quality function deployment planning for platform design. Int J Adv Manuf Technol 36:419-430. https://doi.org/10.1007/s00170-006-0853-3

Jiao J, Helander MG (2006) Development of an electronic configure-to-order platform for customized product development. Comput Ind 57:231-244. https://doi.org/10.1016/j.compind.2005.12.001

Jiao J, Tseng MM (2004) Customizability analysis in design for mass customization. Comput Aided Des 36:745-757. https://doi.org/10.1016/j.cad.2003.09.012

Jiao J, Simpson TW, Siddique Z (2007) Product family design and platform-based product development: a state-of-the-art review. J Intell Manuf 18:5-29. https://doi.org/10.1007/s10845-007-0003-2

Karlsson C, Sköld M (2007) Counteracting forces in multi-branded product platform development. Creat Innov Manag 16:133-142. https://doi.org/10.1111/j.1467-8691.2007.00432.x

Khajavirad A, Michalek JJ, Simpson TW (2009) An efficient decomposed multiobjective genetic algorithm for solving the joint product platform selection and product family design problem with generalized commonality. Struct Multidiscip Optim 39:187-201. https://doi.org/10.1007/s0015 8-008-0321-9

Kondracki NL, Wellman NS, Amundson DR (2002) Content analysis: review of methods and their applications in nutrition education. J Nutr Educ Behav 34:224-230

Koufteros XA, Vonderembse MA, Jayaram J (2005) Internal and external integration for product development: the contingency effects of uncertainty, equivocality, and platform strategy. Decis Sci 36:97-133

Krishnan V, Gupta S (2001) Appropriateness and impact of platform-based product development. Manag Sci 47:52-68

Leonard-Barton D (1992) Core capabilities and core rigidities: a paradox in managing new product development. Strateg Manag J 13:111-125

Li L, Huang GQ, Newman ST (2007) Interweaving genetic programming and genetic algorithm for structural and parametric optimization in adaptive platform product customization. Robot Comput Integr Manuf 23:650-658. https://doi.org/10.1016/j.rcim.2007.02.014

Lundbäck M, Karlsson C (2005) Inter-firm product platform development in the automotive industry. Int J Innov Manag 9:155-181

Luo X, Tang J, Kwong CK (2010) A QFD-based optimization method for a scalable product platform. Eng Optim 42:141-156. https://doi.org/10.1080/03052150903104333

Magnusson M, Pasche M (2014) A contingency-based approach to the use of product platforms and modules in new product development. J Prod Innov Manag 31:434-450. https://doi.org/10.1111/ jpim. 12106

Makadok R (2001) Toward a synthesis of the resource-based and dynamic-capability views of rent creation. Strateg Manag J 22:387-401

Maniak R, Midler C, Beaume R, von Pechmann F (2014) Featuring capability: how carmakers organize to deploy innovative features across products. J Prod Innov Manag 31:114-127. https://doi. org/10.1111/jpim.12083

Martin MV, Ishii K (2002) Design for variety: developing standardized and modularized product platform architectures. Res Eng Des 13:213-235. https://doi.org/10.1007/s00163-002-0020-2

McGrath ME (1995) Product strategy for high technology companies. Irwin Professional Publishing, NewYork

Meyer MH, Dalal D (2002) Managing platform architecture and manufacturing processes for nonassebled products. J Prod Innov Manag 19:277-293

Meyer MH, De Tore A (2001) Perspective: creating a platform-based approach for developing new service. J Prod Innov Manage 18:188-204

Meyer MH, Lehnerd AP (1997) The power of product platform: building value and cost leadership. Free Press, New York 
Meyer MH, Utterback JM (1993) The product family and the dynamics of core capability. Sloan Manag Rev 34:29-47

Meyer MH, Tertzakian P, Utterback JM (1997) Metrics for managing research and development in the context of the product family. Manag Sci 43:88-111

Muffatto M (1999) Introducing a platform strategy in product development. Int J Prod Econ 60-61:145153. https://doi.org/10.1016/S0925-5273(98)00173-X

Muffatto M, Panizzolo R (1996) Innovation and product development strategies in the Italian motorcycle industry. J Prod Innov Manag 13:348-361

Muffatto M, Roveda M (2000) Developing product platforms: analysis of the development process. Technovation 20:617-630

Nayak RU, Chen W, Simpson TW (2002) A variation-based method for product family design. Eng Optim 34:65-81. https://doi.org/10.1080/03052150210910

Otto K, Hölttä-Otto K (2007) A multi-criteria assessment tool for screening preliminary product platform concepts. J Intell Manuf 18:59-75. https://doi.org/10.1007/s10845-007-0004-1

Park J, Shin D, Insun P, Hyemi H (2008) A product platform concept development method. J Eng Des 19:515-532. https://doi.org/10.1080/09544820802043583

Pasche M, Persson M, Löfsten H (2011) Effects of platforms on new product development projects. Int J Oper Prod Manag 31:1144-1163. https://doi.org/10.1108/01443571111178475

Peteraf MA (1993) The cornerstones of competitive advantage: a resource-based view. Strateg Manag J 14:179-191

Pirmoradi Z, Wang GG, Simpson T (2014) A review of recent literature in product family design and platform-based product development. In: Simpson TW, Jiao J, Siddique Z, Hölttä-Otto K (eds) Advances in product family and product platform design. Springer, New York, pp 1-46. https://doi. org/10.1007/978-1-4614-7937-6_1

Qu T, Bin S, Huang GQ, Yang HD (2011) Two-stage product platform development for mass customisation. Int J Prod Res 49:2197-2219. https://doi.org/10.1080/00207541003738881

Ramdas K (2003) Managing product variety: an integrative review and research directions. Prod Oper Manag 12:79-101

Robertson D, Ulrich K (1998) Planning for product platforms. Sloan Manag Rev 39:19-31

Rumelt RP, Dan S, Teece DJ (1991) Strategic management and economics. Strateg Manag J 12:5-29

Sanderson S, Uzumeri M (1995) Managing product families: the case of the Sony Walkman. Res Policy 24:761-782

Sawhney MS (1998) Leveraged high-variety strategies: from portfolio thinking to platform thinking. Acad Mark Sci 26:54-61

Shooter SB, Simpson TW, Kumara SRT, Stone RB, Terpenny JP (2005) Toward a multi-agent information management infrastructure for product family planning and mass customisation. Int $\mathrm{J}$ Mass Cust 1:134-155

Shooter SB, Evans CM, Simpson TW (2007) Building a better ice scraper-a case in product platforms for the entrepreneur. J Intell Manuf 18:159-170. https://doi.org/10.1007/s10845-007-0010-3

Simpson TW, D'Souza BS (2004) Assessing variable levels of platform commonality within a product family using a multiobjective genetic algorithm. Concurr Eng Res Appl 12:119-129. https://doi. org/10.1177/1063293X04044383

Simpson TW, Maier RAJ, Mistree F (2001) Product platform design: method and application. Res Eng Des 13:2-22

Simpson TW, Marion T, Olivier DW, Katja H-O, Kokkolaras M, Shooter SB (2006) Platform-based design and development: current trends and needs in industry. Paper presented at the ASME 2006 international design engineering technical conference and computers and information in engineering conference Philadelphia, Pennsylvania, USA 10-13 Sept 2006

Sirmon DG, Hitt MA, Ireland RD (2007) Managing firm resources in dynamic environments to create value: looking inside the black box. Acad Manag Rev 32:273-292

Sirmon DG, Hitt MA, Ireland RD, Gilbert BA (2011) Resource orchestration to create competitive advantage: breadth, depth, and life cycle effects. J Manag 37:1390-1412. https://doi.org/10.1177/01492 06310385695

Sköld M, Karlsson C (2013) Stratifying the development of product platforms: requirements for resources, organization, and management styles. J Prod Innov Manag 30:62-76. https://doi. org/10.1111/jpim.12064

Suh ES, de Weck OL, Chang D (2007) Flexible product platforms: framework and case study. Res Eng Design 18:67-89. https://doi.org/10.1007/s00163-007-0032-z 
Tatikonda MV (1999) An empirical study of platform and derivative product development projects. Prod Innov Manag 16:3-26

Teece DJ, Pisano G, Shuen A (1997) Dynamic capabilities and strategic management. Strateg Manag J 18:509-533

Thevenot HJ, Simpson TW (2006) Commonality indices for product family design: a detailed comparison. J Eng Des 17:99-119. https://doi.org/10.1080/09544820500275693

Thevenot HJ, Simpson TW (2007) A comprehensive metric for evaluating component commonality in a product family. J Eng Des 18:577-598. https://doi.org/10.1080/09544820601020014

Thomas E (2014) Platform-based product design and environmental turbulence: the mediating role of strategic flexibility. Eur J Innov Manag 17:107-124

Wei W, Feng Y, Tan J, Li Z (2009) Product platform two-stage quality optimization design based on multiobjective genetic algorithm. Comput Math Appl 57:1929-1937. https://doi.org/10.1016/j.camwa .2008 .10 .022

Wernerfelt B (1984) A resource-based view of the firm. Strateg Manag J 5:171-180

Wernerfelt B (1989) From critical resources to corporate strategy. J Gen Manag 14:4-12

Wheelwright S, Clark K (1992) Revolutionizing new product development. The Free Press, New York

Zha XF, Sriram RD (2006) Platform-based product design and development: a knowledge-intensive support approach. Knowl-Based Syst 19:524-543. https://doi.org/10.1016/j.knosys.2006.04.004

Zhu F, Iansiti M (2012) Entry into platform-based markets. Strateg Manag J 33:88-106 